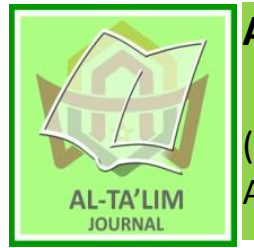

AL-TA'LIM JOURNAL, 25 (2), 2018, (144-152)

(Print ISSN 1410-7546 Online ISSN 2355-7893)

Available online at http://journal.tarbiyahiainib.ac.id/index.php/attalim

\title{
EFL Teachers' Perceptions on Supervision Program as a Tool to Develop Teachers' Professionalism
}

\author{
Received: 13 ${ }^{\text {th }}$ January 2018; Revised:01 ${ }^{\text {st }}$ March 2018; Accepted: $24^{\text {th }}$ July 2018 \\ Permalink/DOI: http://dx.doi.org/10.15548/ jt.v25i2.373
}

\section{Tosriadi *)}

Universitas Sebelas Maret, Surakarta, Indonesia.

E-Mail: adytandjung7@gmail.com

\section{Abdul Asib \\ Universitas Sebelas Maret, Surakarta, Indonesia \\ E-Mail: abdulasib01@gmail.com}

\section{Sri Marmanto}

Universitas Sebelas Maret, Surakarta, Indonesia E-Mail:

srimarmanto01@gmail.com

\section{*) Corresponding Author}

\begin{abstract}
Teachers hold a very crucial role in education. Students' success in academic life is very much influenced by teachers' quality. One of the ways applied by most schools in Indonesia to assure their teachers quality is by conducting supervision program at the end or in the middle of semester. This study investigated teachers' perception on the effectiveness of supervision program in relation to their professional development. This qualitative case study involved 4 EFL teachers teaching at various school levels; elementary school, junior high school and senior high school. The data were collected through interview and document analysis. The result of data analysis revealed that teachers hold positive attitude toward supervision program in helping them develop their professionalism in teaching. Schools need to maintain supervision program to make sure their teachers are well prepared in performing their duty. The participating teachers suggested for its meaningfulness, supervision program should be well designed. Teachers being observed and supervisor should have the same educational background.
\end{abstract}

Keywords: Teachers' assessment; supervision program; teachers' professionalism; professional development.

How to cite: Tosriadi, T., Asib, A., \& Marmanto, S. (2018). EFL teachers' perceptions on supervision program as a tool to develop teachers' professionalism. Al-Ta Lim Journal, 25(2). doi:http://dx.doi.org/10.15548/jt.v25i2.373

\section{INTRODUCTION}

In this global era, in order to be able to compete with people from other countries, English communication skill is needed (Ushioda, 2013). Considering the status of English as international language, Indonesian government has included English as a compulsory subject into education curriculum. Lamb $(2004,2007)$ stated that English teachers' role in teaching English is very important. Unfortunately, lately the teaching of English in Indonesia has been considered failed due to some reasons, one of which is teachers' competency. (Sulistiyo,
2015) said the teaching of English Indonesia has shown limited success due to some factors such as lack of pedagogy skill and insufficient English competence. (Mattarima \& Hamdan, 2011; Sysoyev \& Evstigneev (2014) said only few of Indonesian students can communicate in English, although they have learned English for years. On the other side, (Yulia, 2014) in her study related to evaluation to English language teaching in Indonesia, she found teachers' limited capacity in the teaching of English as a major finding. Most teachers had insufficient capacity, in particular, regarding the pedagogical and professional aspects. 
Kirkpatrick (2007) emphasized that English teaching in Indonesian schools cannot operate successfully since there is an absence of suitably qualified teachers.

Regarding to the discrepancy between the needs for quality teachers and the reality, teachers are supposed to do any activities to support the development of their professionalism. Hartono (2016) argued that teachers' professional development is an individual responsibility. Which means, every teacher should find ways to develop their professionalism? Professional development is defined as an aspect of life learning teachers need to conduct, they need to understand and practice it in formal or informal way (Connell, 2009; Gebhard, 2006; Kabilan, WanMansor, \& Embi, 2011; Samson \& Collins, 2012). Hismanoglu (2010) in his study found that most of English teachers are aware of the importance of professional development for teachers, but unfortunately only around $30 \%$ of the participants give importance to their professional development. While Johnson \& de C. Kuerten Dellagnelo (2015) stated that EFL teaching is not an easy thing, this is why EFL teachers need to get involved in professional development activities to help them develop a meaningful teaching.

There are so many professional development activities to support teachers' professionalism, whether it is institutional or individual (Faltis, Arias, \& Ramírez-Marín, 2010; McCann, Johannessen, \& Ricca, 2005; Rice, 2003; Siwatu, 2007). One of the activities that can be held is academic supervision. Academic supervision is a regular activity conducted at most schools in Indonesia to evaluate teaching and learning processes carried out by teachers in the classroom. It is usually conducted by planned, in this case schools (principals/people in charge) will create the agenda for supervision program, and then at the due time teachers teach in their classroom under supervision of school principal or super intendment (French, 2001; Nir \& Bogler, 2008). Sometimes, supervision can also be conducted incidentally which means there is no fixed schedule for supervision. Rahmany, Hasani, \& Parhoodeh, (2014a) said academic supervision is a challenging effort in evaluation. Further, they argued this program is expected to improve the quality of teachers' instruction.

In educational context, supervision is defined as "An ongoing process of teachers education in which supervisor observes what goes on in the teacher's classroom with an eye toward the goal of improved instruction" (Glickman, Gordon, \& Ross-Gordon, 2001; Howard, 2018). Uys, Minnaar, Simpson, \& Reid (2005) classified the models of supervision program into nominal, correcting, and reflective. The main goal of the first model, nominal supervision, is maintaining the existing state or condition. This type of supervision is preferably applied when there is limited time or when the supervisor attempts to accede with standard legal requirements.

The second model, the prescriptive model, is aimed to diagnose the problem and subsequently treating it. Thus, in this model, the supervisor is expected to possess diagnostic skills and considerably higher knowledge than the teacher being supervised, in order to maximize the benefits and the meaningfulness of the program. The final model of reflective supervision leads teachers to think about their teaching as much as their actual teaching behavior. The reflective model "is based upon using and developing the expertise of the teacher to examine ideal purposes and procedures for teaching, and to refine present performance accordingly" (Certo, 2003). Based on supervisor role during the supervision, Kaufman \& Schwartz (2004) elaborated the some model of supervision. Specifically the roles are judgmental, non-judgmental, clerical, cooperative, responsive and clinical supervision. Other expert suggested three approaches to teacher supervision depending on the role of the supervisor: 1) the supervisor as an authority 2) the supervisor as a provider of alternative perspectives 3 ) 
the supervisor as non-directive figure (Ebmeier, 2003; Nolan \& Hoover, 2004).

The focus of this study is to look at teachers' perception on the effectiveness of supervision program conducted by school principal or super intendment in developing their professionalism. The regulation of the Government of Indonesia number 14 year 2005 (Dikti, 2016) on teachers and lecturers has mandated there are four competences teachers should have, namely; pedagogic competence, personal competence, social competence, and professional competence. Supervision is expected to help teachers develop those competences.

The importance of supervision program for teachers cannot be underestimated. Esia-Donkoh \& OfosuDwamena (2014) in their study found that educational supervision is very vital in the professional development. Through supervision teachers will receive some feedbacks related to how to conduct teaching and learning more meaningful. Mette, Range, Anderson, Hvidston, \& Nieuwenhuizen (2015); Mette et al., (2017) found in their study that supervision is very important to improve teachers' classroom instruction and it also relates to students' achievement. Another study conducted by Veloo, Komuji, \& Khalid (2013) confirmed that supervision program helps teacher design a more effective teaching and learning process.

\section{METHOD}

This study was a qualitative study. It investigated language teachers' perceptions on the effectiveness of supervision program done by super intending or person in charge in developing teacher professional development. Suited to the goal of the study, qualitative case study design was employed. This study involved four English teachers who currently served as active English teachers at various levels of school; elementary school, junior high school, and senior high school. The samples were selected through purposive sampling approach. Since this study was designed to investigate teachers' perceptions on the effectiveness of supervision program in developing their professionalism, some criteria for the research sample selection were applied to achieve the objective, 1. They should pose at least one year teaching experience, 2. They have ever gone through the supervision program.

There were several sources of data, namely informants and documents. The data were collected through interview with participants and document analysis (supervision document). Prior to the interview, interview protocol was designed carefully to meet the goal of the study. The interview was carried out to 2 senior high school (SMA) English teachers and 1 junior high school (SMP) and 1 private Islamic elementary school. The teachers are Mr. Indra, Mrs. Diana, Mr. Rahman, and Miss. Lilian (Pseudonyms). The participating teachers were asked to answer some questions related to professional development and supervision program. Those questions are; 1 . What do you think about professional development and how do you define a professional teacher? How important is professional development for you as a teacher and what impact does it bring to your students? 2. What is the challenge you face in developing your professionalism? 3. What activities do you involve in to develop your professionalism? 4. What do you think about supervision by super intendment to develop teachers' professionalism? Do you think it brings positive impact on teachers? 5 . What are the benefits of supervision for your teaching professionalism? What aspects does it improve? 6. What do you expect from supervision? How is the ideal frequency of supervision in one year? And what are the challenges of being supervised? After the interview was conducted, then it was transcribed. The unnecessary data were reduced, and then data analysis was done. Results of the study were presented by using narration. 


\section{RESULT AND DISCUSSION}

The results of the study confirmed the importance of supervision program to help teachers develop their professionalism. The interview which was conducted with four English teachers revealed several points. When defining what professional teacher is, teachers have different perspective. Two teachers, Miss Lilian and Mr. Rahman believe that professional teacher means having good English instruction:

"Professional English teachers have good communication skills in both written and spoken. They can speak English fluently and always use English in the classroom" Miss Lilian. Mr Rahman thought that "A professional teacher knows what he is going to teach. He understands the subject matters well. Not only having good understanding, he also has a very good practical skill of the subject"

While other two teachers, Mrs. Diana and Mr. Indra said almost similar things:

"Teaching is an art. You need to master a certain strategy to be a good teacher. Professional teacher is not about how good your English is, but how clear your instruction is understood by your students"

In term of their awareness of their professional development, the respondents say that they are really aware of the need of professional development, but they are too busy with their rosters. Mr. Rahman, one of the respondents said

"I really know how importance it is to get involved in professional development activities. The world of teaching keeps changing, and teachers are supposed to keep learning. But, I have to teach 28 teaching hours a week, and it does take my time. I have to check students' work, conducting assessment; prepare my teaching, so I do not have time to get involved in professional development, although I want to"

Another respondent, Mrs. Diana said:

"As a certified teacher, I have to teach minimum of 24 hours a week. And I also get other additional work/duty at school, I cannot attend professional development activity out of school program"

In turn, the research respondents also commented on the usefulness of supervision program to improve their professionalism.

"Supervision program is very important for teachers. Sure, it brings positive impacts. We know what our weaknesses are. So can improve it and give our best to our students. So, at the end hopefully we can improve students' achievement" said Miss Lilian

Mr. Indra also argued:

"Supervision is important for teachers. If there is no supervision, no one can guarantee the quality of teaching. Teachers maybe will never do a maximum preparation for their class, so supervision program is very important".

Another respondent, Mrs. Diana argued:

"Through supervision we learn something new. We learn about new techniques in teaching. We also get some useful feedback from superintendent"

One of the areas identified from the interview was the need for feedback. Mr. Indra commented on this:

"Feedback is something useful for teachers. In supervision program we will get some notes related to our performance in classroom. Super intendment will tell us what to 
improve and what to maintain" Teachers generally show their positive attitude toward the feedback they got from the super intendment. As stated by Mr. Rahman "We appreciate the comments. They are mostly constructive and positive. But, sometimes we do not like when the super intendment gives a directive comments, it is not about the content of their comment but about their way in commenting us"

Respondent teachers also proposed
some suggestion for the impactful
supervision program.

"It will be better if the super intendment has the same educational background with teachers being supervised. So, it will bring so many useful insight for teachers" stated by Mrs. Diana.

Another respondent in this current study, Mr. Indra also said:

"I ever got supervised by super intendment who had different field from me. I appreciate his feedbacks, but I think it is much better if they have the same field with me"

While Mrs. Diana argued:

"I was once supervised by super intendent whose major was totally different from mine. I didn't know if he understood English well. My suggestion is for a betterment of the supervision program supervisors and teachers under supervision should have the same educational background, so they can provide insightful views"

Related to the usefulness of supervision program to develop teachers' professionalism all respondents agree that supervision helps them develop their professionalism.
Miss Lilian said "supervision by principal or super intendent help me develop my pedagogy skill. I got some useful inputs about good teaching" And further, she said "supervision program should be conducted regularly, at least twice a year"

\section{Teachers' perception toward professional development}

This current study has explored the English teachers' perception on the effectiveness of supervision program by super intendment in developing their professionalism. The conceptual framework for this research is based on the premise that teacher as an actor in the field of education should be professional in order to enable them reach certain educational goals.

This study revealed that English teachers hold different perspectives toward the definition of professional development in educational world. Teachers assumed that professional development is about having good English (mastery of content knowledge) or good classroom management. Depdikbud in (Yamin, 2013) stated several standard competences of professional teacher: a). the mastery of learning material and the basic concept, b) management of teaching and learning, c) classroom management, d) the use of teaching media, e) the mastery of educational foundation, $f$ ) the management of teaching-learning interaction, g) conducting the evaluation, $h$ ) introduction of functions and programs of guidance and counselling, i) implementation of school administration, $j$ ) understanding the utilization of research report for educational purposes. While the regulation of republic of Indonesia number 14, 2005 of regulation of teachers and lecturers offered a broader competences of a professional teacher, instead of pedagogy and professional competences, it also covers personal and social competences. 


\section{The importance of professional development activities}

Research finding showed teachers are really aware of the importance of professional development for them. Teachers realize that they are the actor in education. Heydari \& Abbasian (2016) considered teachers as the main angle of education, and they have to do well to reach the instructional goals. Kennedy (2016) stated through professional development teachers develop their teaching. But, unfortunately the ideal condition does not always meet in the real practice. Hismanoglu (2010) found most teachers are aware of the importance of professional development, but only around $30 \%$ of the participants pay good attention to their ongoing professional development. The finding of this study explained the same thing. The participants know the importance of professional development, but they are trapped by several regular activities, such as heavy load teaching hours. The government regulation of Republic of Indonesia number 19, 2017 ("Peraturan Pemerintah Republik Indonesia No 19 Tahun 2017," 2017) on teachers stated that teachers have the responsibility to teach of the minimum 24 teaching hour a week and of the maximum 40 teaching hour. This regulation makes teachers busy with their teaching job, in addition they still have to do several other activities such us, guiding student, preparing lesson plan, preparing learning aids, conducting assessment, doing evaluation, etc. the respondents of the research expressed that teaching loads have become the primary obstacle for them to develop their professionalism through professional development activity. Thus, it should be the concern of many parties, including government as the policy maker.

\section{Reflection through supervision program}

Supervision program can be a source of reflective analysis for teachers. As a part of reflective practices, supervision provides teachers with some feedbacks as evaluation for their strengths and weaknesses. There are several studies have been conducted related to supervision program. A study conducted by Regassa, To, Ferede, Hunde, \& Lemma (2013) revealed that there is no improvement of supervision program toward teachers' professionalism. This is due to several conditions such as teachers' lack of preparation for supervision or less experienced supervisors. They are unable to give good feedbacks for teachers. Other study conducted by Rahmany, Hasani, \& Parhoodeh (2014b) found that less experience teachers with teaching experience of 1-5 years are more influenced by the supervision, while teachers with more than 5 years teaching experience are more pessimist on supervision program. Another study by Sudarjat, Abdullah, \& Sunaryo (2015) stated that there is a correlation between supervision with teacher's teaching. It is believed that supervision can boost teachers' performance. The latest finding yields the same result with this current study. The participating teachers believe that supervision can improve their professional competences, especially related to pedagogical competence. As stated by Adewale, Adenowo, Toyin, \& Odusoga (2014) supervision and teachers' performance in the classroom are closely related. Supervision gives opportunity for teachers to show their best of classroom instruction.

Chen \& Cheng (2013) argued that supervision is a part of teachers' professional experiences. As aforementioned by some respondents, it helps them be a better teacher. It forces them to do their job at the maximum level since they are going to be supervised, in other words they will be scored related to their teaching ability. Comfort Ayandoja, Caroline Aina, \& Femi Idowu (2017) stated "Supervision is the process of overseeing the work of teachers with the aim of assisting them to solve their instructional problems so that students can benefit maximally from classroom activities". To sum up, supervision is fruitful for teachers for some respects. It is aimed to help teachers overcome their classroom problem. So, it should be 
maintained and its quality should be improved to make a meaningful input for teachers.

\section{CONCLUSIONS AND RECOMMENDATION}

Based on the aforementioned results and discussions, some conclusions are drawn related to this study. First, teachers' have different perceptions toward what a professional teacher are. Second, language teachers hold positive perceptions toward the supervision program conducted by super intending or person in charge in developing their professionalism. Third, teachers believe that supervision program affect their professionalism. It "forces" them to be a well-prepared teacher since they have to plan everything for their students, start from opening the meeting, delivering the topic, and even conducting the evaluation. Fourth, to make it effective, supervision program should be conducted simultaneously; at least two times a year and it should be supported with other kind of professional development activities. So, teacher cannot only rely on supervision program to help them develop their professionalism. And the last, it will be better if super intendments who conducted the supervision have the same educational background (major) with the teacher being supervised. This research reported that supervisor quality is another challenge in conducting supervision as a part of teacher professional development

Some suggestions are also offered regarding the results of the study; to school principal, it is very important to conduct the supervision program carefully since it brings positive impact to teachers. So make it meaningful, not only as administration matter. To other researchers, it is very important to conduct further research with a wider research participants to gain more comprehensive data and conclusions. And also it is needed to check teachers' professionalism from students' perspective.

\section{REFERENCES}

Adewale, O. S., Adenowo, E. A., Toyin, A. F., \& Odusoga, R. (2014). School inspection or, and supervision effects in public secondary schools in Ogun State, Nigeria: Where are we and where do we go? International Journal of Humanities and Social Science Invention, 3(6), 74-80.

Certo, S. C. (2003). Supervision: Concepts and skill-building. McGraw-Hill New York, NY.

Chen, C. W.-Y., \& Cheng, Y. (2013). The Supervisory process of EFL teachers : A Case Study. The Electronic Journal for English as a Second Language, 17(1), 1-21.

Comfort Ayandoja, A., Caroline Aina, B., \& Femi Idowu, A. (2017). Academic supervision as a correlate of students' academic performance in secondary schools in Ekiti State, Nigeria. International Journal of Educational Policy Research and Review, 4(1), 813. https://doi.org/10.15739/IJEPRR.17.0 02

Connell, R. (2009). Good teachers on dangerous ground: Towards a new view of teacher quality and professionalism. Critical Studies in Education, 50(3), 213-229.

Ebmeier, H. (2003). How supervision influences teacher efficacy and commitment: An investigation of a path model. Journal of Curriculum and Supervision, 18(2), 110-141.

Esia-Donkoh, K., \& Ofosu-Dwamena. (2014). Effect of educational supervision on professional development: Perception of public basic school teachers at Winneba, Ghana, 2(6), 63-82.

Faltis, C., Arias, M. B., \& Ramírez-Marín, F. (2010). Identifying relevant 
competencies for secondary teachers of English learners. Bilingual Research Journal, 33(3), 307-328.

French, N. K. (2001). Supervising paraprofessionals: A survey of teacher practices. The Journal of Special Education, 35(1), 41-53.

Gebhard, J. G. (2006). Teaching English as a foreign or second language: A teacher self-development and methodology guide. University of Michigan Press.

Glickman, C. D., Gordon, S. P., \& RossGordon, J. M. (2001). Supervision and instructional leadership: A developmental approach. ERIC.

Hartono, R. (2016). Indonesian EFL teachers perceptions and experiences of professional development. Indiana University of Pennsylvania.

Heydari, S., \& Abbasian, G.-R. (2016). The relationship between Iranian EFL teachers' professional development and their job burnout 1. Basic Research Journal of Education Research and Review Basic Research Journal of Education Research and Review ISSN, 4(2), 2315-6872.

Hismanoglu, M. (2010). Effective professional development strategies of English language teachers. Procedia Social and Behavioral Sciences, 2(2), 990-995. https://doi.org/10.1016/j.sbspro.2010. 03.139

Howard, S. (2018). Models of supervision. In On Supervision (pp. 63-87). Routledge.

Johnson, K. E., \& de C. Kuerten Dellagnelo, A. (2015). L2 / FL Teacher Education: Bridging the Complexities of Teaching and the Learning of Teaching. Ilha Do Desterro, 68(1), 11-16. https://doi.org/10.5007/21758026
Kabilan, M. K., WanMansor, W. F. A., \& Embi, M. A. (2011). Online Collaboration of English language teachers for meaningful professional development experiences. English Teaching: Practice and Critique, 10(4), 94-115.

Kaufman, J., \& Schwartz, T. (2004). Models of supervision: Shaping professional identity. The Clinical Supervisor, 22(1), 143-158.

Kennedy, M. M. (2016). How Does Professional Development Improve Teaching? Review of Educational Research, 86(4), 945-980. https://doi.org/10.3102/00346543156 26800

Kirkpatrick, A. (2007). Teaching English across cultures. What do English language teachers need to know to know how to teach English. English Australia Journal, 23(2), 20.

Lamb, M. (2004). Integrative motivation in a globalizing world. System, 32(1), 319.

Lamb, M. (2007). The impact of school on EFL learning motivation: An Indonesian case study. Tesol Quarterly, 41(4), 757-780.

Mattarima, K., \& Hamdan, A. R. (2011). The teaching constraints of English as a foreign language in Indonesia: The Context of School Based Curriculum. Sosiomunika, 4(2), 287-300.

McCann, T. M., Johannessen, L. R., \& Ricca, B. P. (2005). Supporting Beginning English Teachers: Research and Implications for Teacher Induction. ERIC.

Mette, I. M., Range, B. G., Anderson, J., Hvidston, D. J., \& Nieuwenhuizen, L. (2015). Teachers' Perceptions of teacher supervision and evaluation: a reflection of school improvement practices in the age of reform. 
Education Leadership Review, 16(1), 16-30.

Mette, I. M., Range, B. G., Anderson, J., Hvidston, D. J., Nieuwenhuizen, L., \& Doty, J. (2017). The wicked problem of the intersection between supervision and evaluation. International Electronic Journal of Elementary Education, 9(3), 709724.

Nir, A. E., \& Bogler, R. (2008). The antecedents of teacher satisfaction with professional development programs. Teaching and Teacher Education, 24(2), 377-386.

Nolan, J. F., \& Hoover, L. A. (2004). Teacher supervision and evaluation. Wiley.

Rahmany, R., Hasani, M. T., \& Parhoodeh, K. (2014a). EFL teachers' attitudes towards being supervised in an EFL context. Journal of Language Teaching and Research, 5(2), 348359.

https://doi.org/10.4304/jltr.5.2.348359

Regassa, T., To, T., Ferede, B., Hunde, A. B., \& Lemma, A. (2013). An exploration of the utilization of supervision feedbacks: The case of some secondary schools in Jimma Zone, 3(6), 309-318. https://doi.org/10.5923/j.edu.2013030 6.05

Rice, J. K. (2003). Teacher quality: Understanding the effectiveness of teacher attributes. ERIC.

Samson, J. F., \& Collins, B. A. (2012). Preparing All Teachers to Meet the Needs of English Language Learners: Applying Research to Policy and Practice for Teacher Effectiveness. Center for American Progress.
Siwatu, K. O. (2007). Preservice teachers' culturally responsive teaching selfefficacy and outcome expectancy beliefs. Teaching and Teacher Education, 23(7), 1086-1101.

Sudarjat, J., Abdullah, T., \& Sunaryo, W. (2015). Supervision, Leadership, and Working Motivation to Teachers' Performance. International Journal of Managerial Studies and Research (IJMSR), 3(6), 146-152.

Sulistiyo, U. (2015). Improving English as a foreign language teacher education in Indonesia: The case of Jambi University, 328.

Sysoyev, P. V., \& Evstigneev, M. N. (2014). Foreign language teachers' competency and competence in using information and communication technologies. Procedia-Social and Behavioral Sciences, 154, 82-86.

Ushioda, E. (2013). International perspectives on motivation: Language learning and professional challenges. Springer.

Uys, L. R., Minnaar, A., Simpson, B., \& Reid, S. (2005). The effect of two models of supervision on selected outcomes. Journal of Nursing Scholarship, 37(3), 282-288.

Veloo, A., Komuji, M. M. A., \& Khalid, R. (2013). The effects of clinical supervision on the teaching performance of secondary school teachers. Procedia-Social and Behavioral Sciences, 93, 35-39.

Yamin, M. (2013). Ideologi dan kebijakan pendidikan. Malang: Malang Madani.

Yulia, Y. (2014). an Evaluation of English Language Teaching Programs in Indonesian Junior High Schools. RMIT University. 